\title{
CLINICAL STUDIES ON VERATRUM ALKALOIDS. III. THE EFFECT OF PROTOVERATRINE ON RENAL FUNCTION IN MAN ${ }^{1}$
}

\author{
BY EDWARD MEILMAN, M.D. \\ (From the Departments of Medicine and Pharmacology, Harvard Medical School; and the \\ Medical Research Department, Yamins Research Building, Beth Israel Hospital, \\ Boston, Mass.)
}

(Submitted for publication August 12, 1952; accepted October 31, 1952)

Recent clinical interest in the hypotensive properties of mixtures (1) as well as pure substances from veratrum $(2-4)$ has made it desirable to study the effects of this hypotension on kidney function. Protoveratrine, which was isolated from Veratrum album by Salzberger in 1890 (5), was the first pure alkaloid from veratrum shown to have hypotensive properties in man without significant side effects (2).

Since the hypotension induced by protoveratrine is largely the result of a neurogenic vasodilatation (6-10), it appeared important to determine whether the kidney shared in this, and if so, whether directly as a result of neurogenic vasodilatation within it or indirectly as a result of the systemic hypotension. Freis and his associates (11) have studied renal function by clearance methods in ten hypertensive patients who received "veratrone" parenterally or "vertavis" orally. These agents are proprietary preparations from Veratrum viride, containing mixtures of alkaloids and standardized by biological methods. Since they contain substances of varying hypotensive properties and produce side effects $(2,12-14)$ it is desirable to determine the effects on renal function of a single pure alkaloid.

The administration of protoveratrine by various routes offers a method for the controlled lowering of blood pressure (4) during which time physiological measurements of renal function (or cardiac output, cerebral blood flow, peripheral blood flow, and so forth) may be made.

This report is concerned with the effect of protoveratrine-induced hypotension on glomerular filtration rate, effective renal blood flow and renal

1 This investigation was supported by a research grant (PHS-H-121) from the National Heart Institute of the National Institutes of Health, Public Health Service. An abstract of this material appeared in J. Clin. Invest., 30, 659, 1951. resistance, in hypertensive patients with and without chronic renal disease, as well as in some normal individuals.

\section{METHOD}

We have studied renal function 43 times in 36 subjects using familiar clearance technics (15). The subjects were adults from the wards or Out-Patient Department of the Beth Israel Hospital. Twenty-six had essential hypertension, two in the malignant phase; four had documented chronic glomerulonephritis with hypertension; one had Cushing's disease due to carcinoma of the adrenal cortex; one had severe toxemia of pregnancy; four were normal individuals.

Three experiments were carried out in patients who received a single intravenous injection of a hypotensive dose of protoveratrine. Eight studies were made utilizing the intramuscular route. In 32 studies the hypotensive level was maintained at an essentially steady state either by intermittent intravenous injections (e.g., 10 to 30 micrograms every 10 to 30 minutes) or by continuous intravenous infusion of dilute solutions (of the order of 1 microgram per minute). In 17 of this last group of 32, the blood pressure was lowered acutely by an intravenous injection of 100 to 140 micrograms; in 15 it was lowered slowly by infusing protoveratrine at rates of 2.4 to 3.7 micrograms per minute for 20 to 60 minutes. Blood pressure measurements were made at intervals of 2 to 10 minutes by the auscultatory method.

Glomerular filtration rate (GFR) was usually determined by the clearance of inulin, and in a few instances by mannitol ${ }^{3}$ and sodium thiosulfate (Sulfactol ${ }^{4}$ ). Effective renal plasma flow (ERPF) was measured by the clearance of sodium para-amino-hippurate. Inulin was measured by the method of Roe, Epstein, and Goldstein (16), mannitol according to Smith, Finkelstein, and Smith (17), sodium thiosulfate according to Gilman, Philips, and Koelle (18) and para-amino-hippurate by the method of Bratton and Marshall (19). All analyses were performed

${ }^{2}$ Generously supplied by U. S. Standard Products Co., Woodworth, Wisconsin.

${ }^{3}$ Generously supplied by Sharp \& Dohme, Philadelphia, $\mathrm{Pa}$.

4 Generously supplied by Winthrop Chemical Co., New York, N. Y. 
in duplicate. Values for GFR and ERPF were corrected to a body surface area of 1.73 square meters.

The substances for clearance were administered in saline solution (except for one study with intramuscular protoveratrine in which five per cent glucose was used) by an electrically-driven continuous infusion apparatus. Venous blood samples were drawn at the mid-point of each period, with heparin (Liquaemin sodium ${ }^{5}$ ) used as an anticoagulant. Urine collection was through a catheter, and the bladder was rinsed with water and air. In some instances 100 to $200 \mathrm{cc}$. of water was ingested hourly to insure a good urine flow. The first clearance period was begun 30 to 40 minutes after the start of the sustaining infusion. Three control periods (in two instances two periods) of 20 minutes each preceded administration of protoveratrine. Thereafter, clearances were measured for approximately one and one-half hours after single intravenous injection of protoveratrine and for two hours after intramuscular injection. In the 32 experiments in which the hypotension was maintained at a steady low level observations were continued for two to four and one-half hours of hypotension. Clearance periods were usually 30 to $\mathbf{4 0}$ minutes long when urine flow was diminished.

Resistances at the afferent and efferent arterioles were calculated according to the formulae of Lamport (20) and of Gómez (21). Mean blood pressure in the normotensive range was taken as one-half the sum of systolic and diastolic pressures. During hypertensive periods the mean blood pressure was taken as the' sum of diastolic and 0.4 of the pulse-pressure, to minimize the effects of sharply peaked pulse-waves. Renal resistance units (RRU) were calculated as $\frac{\text { mean blood pressure }(\mathrm{mm} . \mathrm{Hg})}{\text { effective renal blood flow (cc. per min.) }}$

\section{RESULTS}

\section{Single intravenous injections of protoveratrine}

In these three experiments there was an abrupt fall in both GFR and ERPF. At the time of maximum hypotension when the mean blood pressure had fallen 24 per cent (range 18 to 28 per cent) the average change in GFR was -28 per cent (range -18 to -42 per cent), the average change in ERPF at this time was -25 per cent (range -18 to -33 per cent). As the blood pressure rose toward control levels GFR and ERPF tended to rise also, the latter back to initial levels. GFR, however, often remained below control values. The final average values of GFR and ERPF, when the blood pressure had almost regained control levels, were reduced by 20 per cent and 11 per cent, respectively. There was a slight tendency for the filtration fraction to de-

\footnotetext{
5 Generously supplied by Organon, Inc., Orange, New Jersey.
}

crease. These results are in contrast to those in a preliminary report of Hoobler (3) who found that renal blood flow was unchanged or slightly increased and glomerular filtration (creatinine or mannitol clearance) unchanged or slightly decreased in similar studies.

In view of the large degree of autonomous control exercised by the kidney (22), it appeared not unlikely that the acute hypotension (from a single large intravenous injection of protoveratrine) might have produced changes in renal function which were modifying any effects from a specific vasodilation due to the drug. Accordingly, experiments utilizing a more gradual fall in blood pressure, as with intramuscular protoveratrine, were made.

\section{Single intramuscular injections of protovera- trine}

The blood pressure fall after intramuscular administration occurs slowly over 30 to 45 minutes, after which it rises in several hours to control levels (4). In these eight experiments the fall of GFR and ERPF was often less than with single intravenous injection and the recovery in function began before the blood pressure had regained control values. The results resemble those obtained by Freis and his associates (11) using veratrone. The average change in GFR during the period of maximum hypotension was -15 per cent (range +5 to -53 per cent) and in ERPF -8 per cent (range +13 to -24 per cent). The final values, when the blood pressure level had almost regained control levels, showed a diminution in GFR of -7 per cent (range +16 to -44 per cent) and in ERPF of -1 per cent (range +13 to -18 per cent).

\section{Continuous or intermittent intravenous infu- sion of protoveratrine}

The comparison of renal function in the hypertensive state with that at lowered blood pressure without regard to fluctuating levels of blood pressure necessitated measurements made while the arterial pressure was maintained at a steady low level for prolonged periods (4). The patients studied under these conditions ${ }^{6}$ included four nor-

- In all of these GFR was measured by clearance of inulin. 


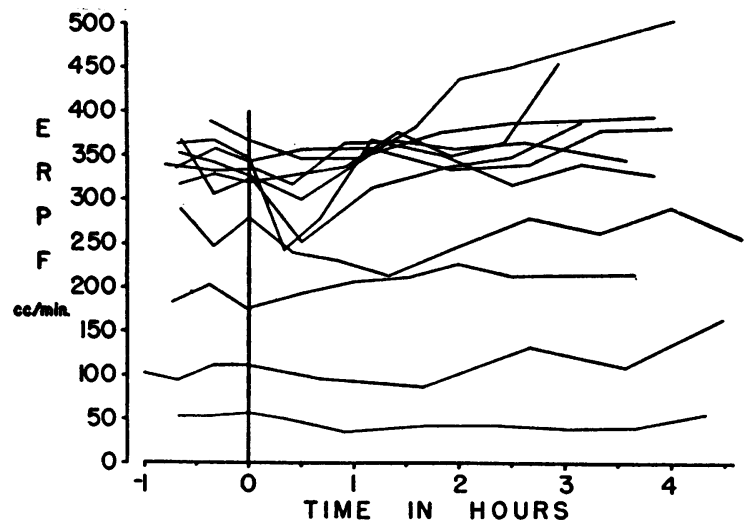

Fig. 1. The Variations of Effective Renal Plasma Flow (ERPF) Before and After Protoveratrine-Hypotension in Eleven Hypertensive Patients

The upper seven had essential hypertension, the next below had chronic nephritis and the next malignant hypertension. The two lowest had chronic glomerulonephritis, one in the malignant phase. At 0 time the blood pressure was lowered with protoveratrine, usually to or near normal levels and maintained at a steady state throughout the remainder of the experiment.

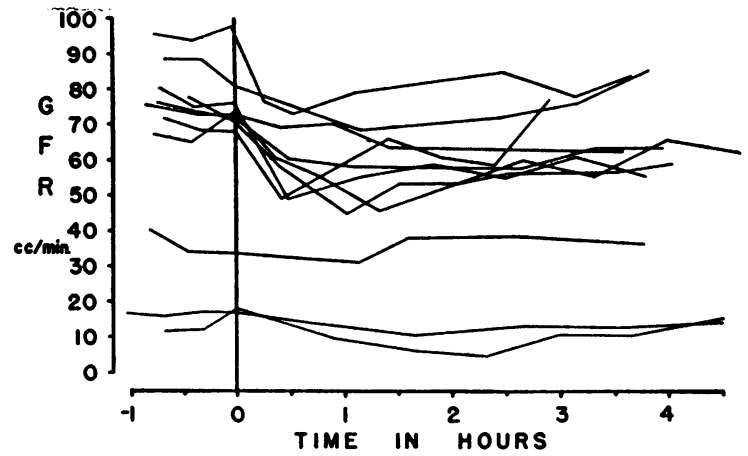

Fig. 2. The Variations of Glomerular Filtration Rate (GFR) Before and After Protoveratrine-Hypotension in the Same Patients as Figure 1

The upper eight include seven with essential hypertension and one with chronic nephritis. The next below is a patient with essential hypertension in the malignant phase. The two lowest are patients with chronic glomerulonephritis, one in the malignant phase.
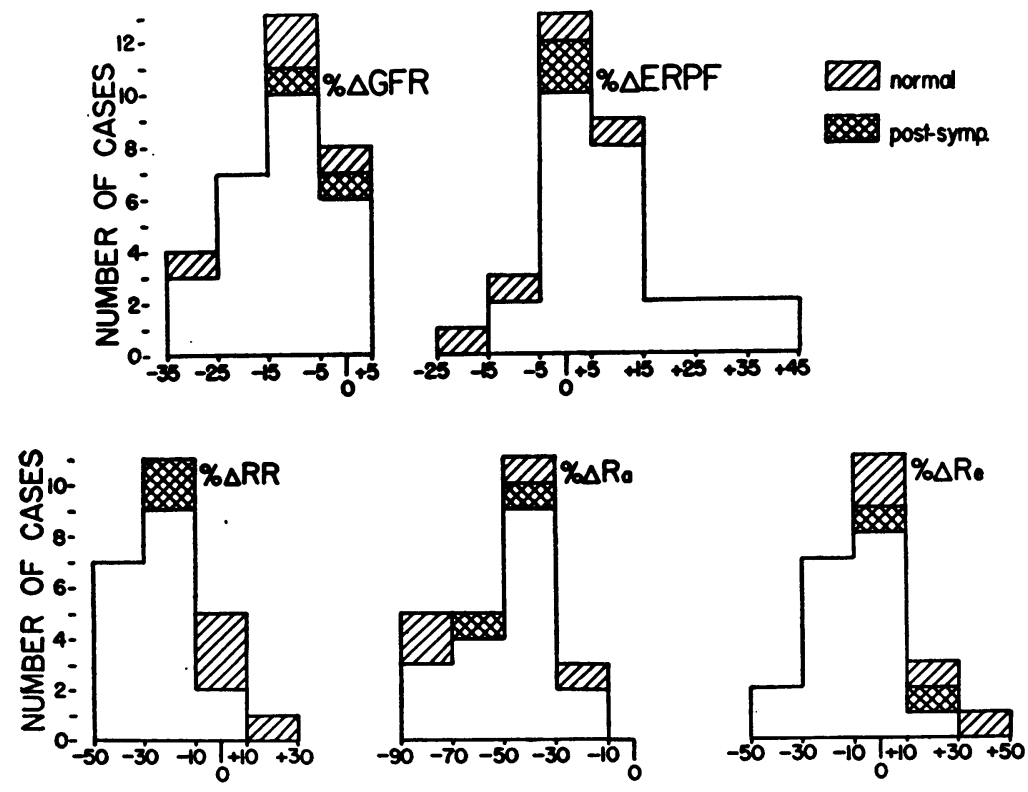

Fig. 3. The Distribution of the Data for the Per Cent Changes in Glomerular Filtration Rate (\% $\%$ GFR), Effective Renal Plasma Flow (\% $\%$ ERPF), Renal Resistance ( $\% \Delta$ RR), Glomerular Afferent Arteriolar Resistance-Lamport ( $\% \Delta \mathrm{Ra})$, and Glomerular Efferent ARteriolar Resistance-Lamport $(\% \Delta \mathrm{Re})$ During Hypotension maintained at a Steady Level for at Least Two Hours

Two patients previously treated with bilateral sympathectomy from $\mathrm{T}-8$ to L-2 are shown in the cross-hatched areas. Four normal individuals are shown in the hatched areas. 
motensive subjects and two patients who had had thoraco-lumbar sympathectomy. In these experiments an average fall in mean blood pressure of 28 per cent (range 19 to 40 per cent) occurred. The changes in ERPF and GFR for eleven of the unoperated hypertensive patients, in whom the hypotension was maintained at a steady low level for at least four hours, are illustrated in Figures 1 and 2. These eleven patients included individuals with ERPF ranging from 50 to almost $400 \mathrm{cc}$. per minute and were typical of the entire group.

The average change in ERPF coincident with the initial fall in blood pressure was -8 per cent (range +8 to -32 per cent) for the 32 experiments. Decrease in ERPF was usually more marked if the blood pressure fall had been abrupt. If the hypotension was induced slowly, e.g., in 60
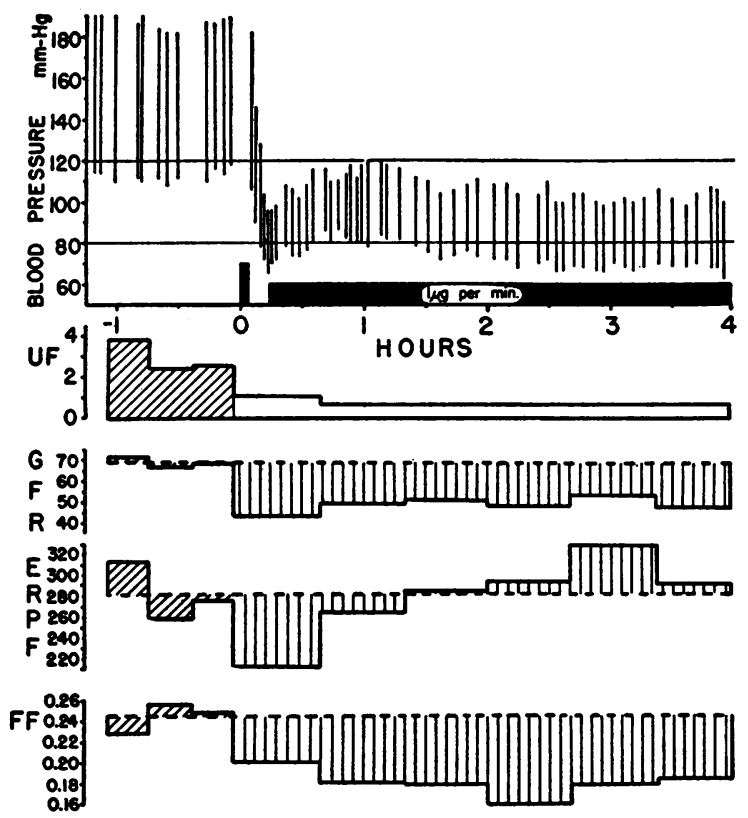

Fig. 4. A Typical Experiment in a 50 Year Old Woman with Essenttal Hypertension

The urine was free of albumin. At 0 time $100 \mu \mathrm{g}$. of protoveratrine was given intravenously. After a delay of 15 minutes a continuous infusion at the rate of $1 \mu \mathrm{g} . / \mathrm{min}$. of protoveratrine was begun and maintained for the duration of the experiment. A typical decrease in urine flow (UF) appeared. The fall in glomerular filtration rate (GFR) was also typical. GFR did not regain control values even after four hours. Effective renal plasma flow (ERPF) which fell initially, reached control values in about one hour. The filtration fraction (FF) was diminished throughout the period of hypotension.
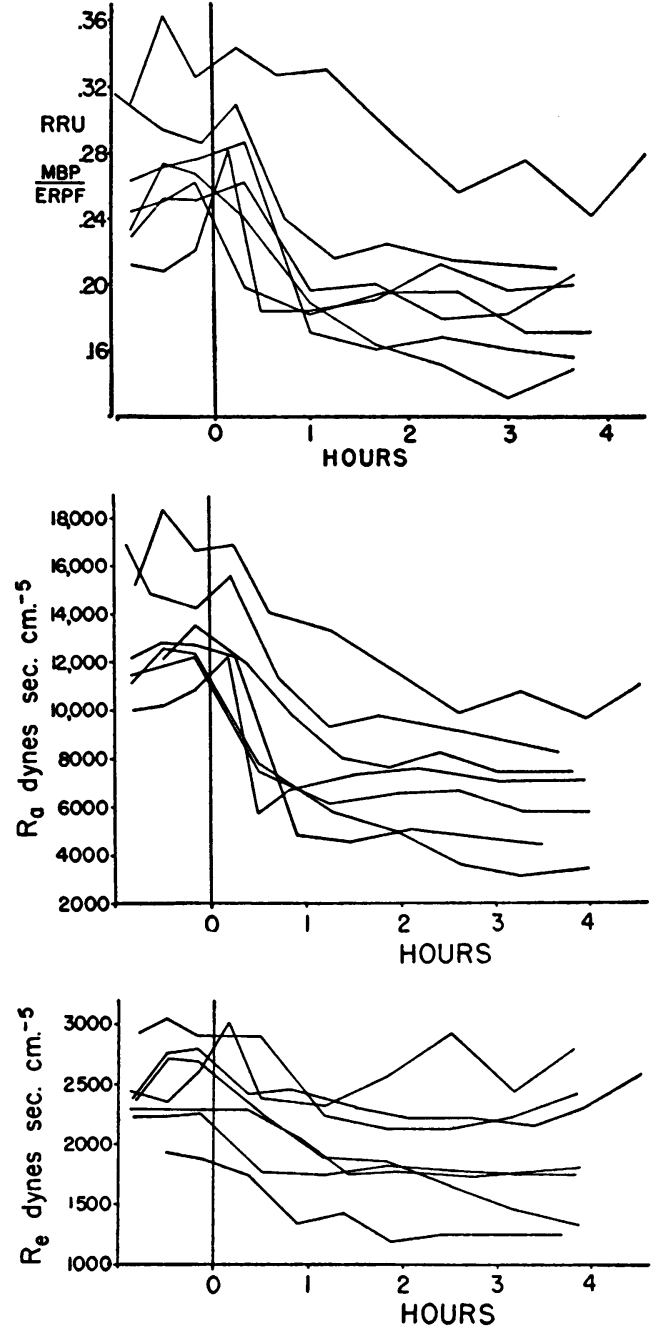

Fig. 5. The Variations of Renal Resistance Units (RRU) [Mean Blood Pressure in ma. Hg/Effective Renal Plasma Flow in cc./Min.], Afferent ResistanCe-Gómez (Ra) and Efferent Resistance-Gómez (Re) in Seven Hypertensive Patients Before and After Lowering the Blood Pressure with ProtoveraTRINE

During the four hours of the hypotensive period the blood pressure was maintained at a steady lowered level (see Table I and text).

minutes, ERPF often remained unchanged. Recovery to control values of ERPF took place in one to one and one-half hours. Thereafter, ERPF remained at these levels or rose considerably above control values although the blood pressure had been maintained at a steady low level throughout this time. The average change in ERPF during 
TABLE I

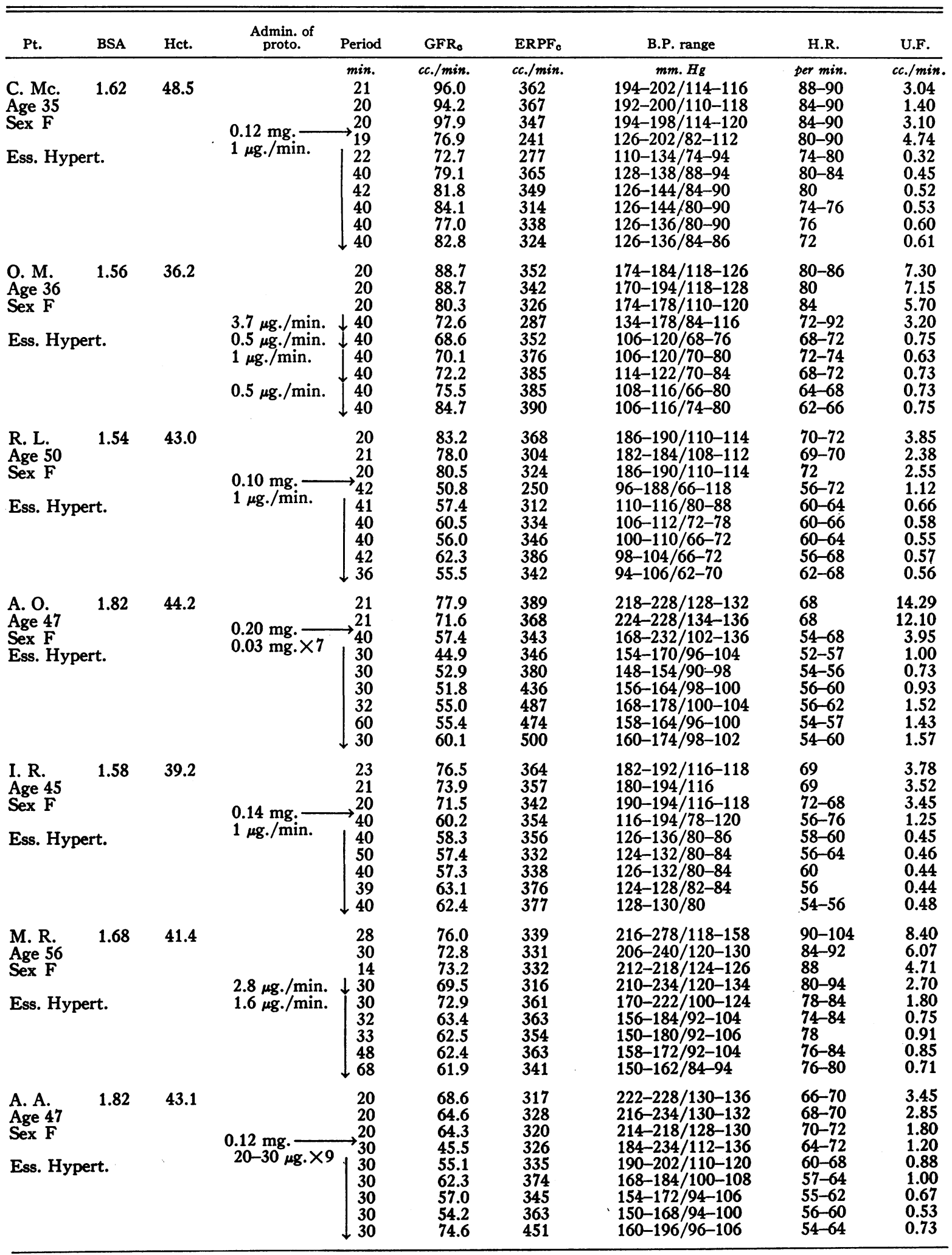


TABLE I-Continued

\begin{tabular}{|c|c|c|c|c|c|c|c|c|c|}
\hline Pt. & BSA & Het. & $\begin{array}{l}\text { Admin. of } \\
\text { proto. }\end{array}$ & Period & $\mathbf{G F R}_{\mathbf{c}}$ & $\mathrm{ERPF}_{\mathrm{c}}$ & B.P. range & H.R. & U.F. \\
\hline $\begin{array}{l}\text { H. F. } \\
\text { Age } 39 \\
\text { Sex F } \\
\text { Chronic }\end{array}$ & 1.85 & 43.1 & $\begin{array}{l}0.14 \mathrm{mg} . \\
0.01-0.03 \mathrm{mg} \\
\text { i.v. } 19 \times\end{array}$ & 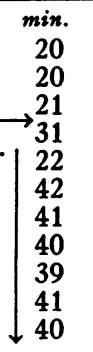 & $\begin{aligned} c c . / \min . \\
67.6 \\
65.0 \\
74.2 \\
58.7 \\
55.4 \\
45.8 \\
52.1 \\
58.8 \\
54.2 \\
63.7 \\
61.0\end{aligned}$ & $\begin{array}{l}c c . / \min . \\
288 \\
245 \\
278 \\
238 \\
230 \\
210 \\
247 \\
277 \\
260 \\
289 \\
251\end{array}$ & \begin{tabular}{l}
\multicolumn{1}{c}{$m m . H g$} \\
$198-214 / 120-130$ \\
$194-208 / 128-130$ \\
$198-210 / 128-130$ \\
$170-216 / 116-130$ \\
$166-178 / 108-120$ \\
$138-152 / 88-100$ \\
$140-156 / 92-98$ \\
$140-152 / 90-92$ \\
$136-148 / 90-96$ \\
$140-150 / 88-95$ \\
$136-150 / 88-96$
\end{tabular} & $\begin{array}{l}\text { per min. } \\
60-66 \\
64-70 \\
66-70 \\
60-74 \\
60-64 \\
57-60 \\
54-64 \\
56-62 \\
54-58 \\
51-60 \\
56-60\end{array}$ & $\begin{array}{c}c c . / \min . \\
8.60 \\
5.40 \\
3.81 \\
2.77 \\
1.41 \\
0.93 \\
0.78 \\
0.83 \\
0.90 \\
1.17 \\
1.20\end{array}$ \\
\hline $\begin{array}{l}\text { A. M. } \\
\text { Age } 37 \\
\text { Sex F } \\
\text { Malig. H }\end{array}$ & pert. & 42.5 & $\begin{array}{l}0.09 \mathrm{mg} .- \\
1 \mu \mathrm{g} . / \mathrm{min} .\end{array}$ & $\begin{array}{r}20 \\
22 \\
\longrightarrow 23 \\
44 \\
\left|\begin{array}{l}30 \\
30 \\
30 \\
30 \\
38 \\
37\end{array}\right|\end{array}$ & $\begin{array}{l}41.1 \\
34.1 \\
33.4 \\
32.5 \\
31.0 \\
37.5 \\
38.0 \\
38.0 \\
37.2 \\
35.9\end{array}$ & $\begin{array}{l}181 \\
201 \\
174 \\
191 \\
207 \\
211 \\
227 \\
211 \\
211 \\
212\end{array}$ & $\begin{array}{l}184-196 / 108-110 \\
194-208 / 108-114 \\
194-198 / 106-108 \\
116-198 / 82-112 \\
146-166 / 84-90 \\
142-154 / 84-86 \\
132-154 / 78-86 \\
140-156 / 84-88 \\
130-172 / 76-102 \\
140-156 / 82-84\end{array}$ & $\begin{array}{l}68-70 \\
67-68 \\
68-72 \\
50-64 \\
60-66 \\
54-60 \\
56-58 \\
56 \\
52-62 \\
52-56\end{array}$ & $\begin{array}{l}5.50 \\
5.09 \\
3.74 \\
1.75 \\
1.33 \\
1.53 \\
1.53 \\
1.15 \\
1.29 \\
1.14\end{array}$ \\
\hline $\begin{array}{l}\text { A. P. } \\
\text { Age } 35 \\
\text { Sex M } \\
\text { Chronic }\end{array}$ & 1.98 & 42.4 & $\begin{array}{l}3 \mu \mathrm{g} . / \mathrm{min} . \\
1 \mu \mathrm{g} . / \mathrm{min} .\end{array}$ & 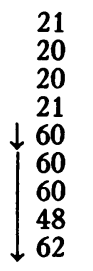 & $\begin{array}{l}16.9 \\
15.7 \\
17.1 \\
17.2 \\
13.6 \\
10.5 \\
13.0 \\
12.6 \\
13.8\end{array}$ & $\begin{array}{r}101 \\
94 \\
110 \\
110 \\
96 \\
85 \\
131 \\
108 \\
162\end{array}$ & $\begin{array}{l}186 / 128 \\
190-206 / 130-144 \\
198-200 / 134-138 \\
184-200 / 132 \\
172-196 / 118-140 \\
120-150 / 80-102 \\
128-136 / 84-90 \\
130-134 / 86-90 \\
130-136 / 86-90\end{array}$ & $\begin{array}{l}60 \\
64 \\
66 \\
\\
52-60 \\
45-48 \\
45-48 \\
44 \\
48\end{array}$ & $\begin{array}{l}2.57 \\
2.75 \\
3.10 \\
3.71 \\
2.53 \\
0.40 \\
1.27 \\
1.73 \\
2.39\end{array}$ \\
\hline $\begin{array}{l}\text { E. P. } \\
\text { Age } 48 \\
\text { Sex F } \\
\text { Chronic }\end{array}$ & 1.45 & 38.0 & $\left.\begin{array}{l}0.11 \mathrm{mg} . \\
\text { atropine } \\
0.2 \mathrm{mg} . \\
1 \mathrm{\mu g} . / \mathrm{min} .\end{array}\right\}$ & $\begin{array}{r}20 \\
20 \\
20 \\
\longrightarrow 21 \\
\longrightarrow 48 \\
\mid \begin{array}{l}42 \\
40 \\
40 \\
40 \\
40\end{array}\end{array}$ & $\begin{aligned} 11.5 \\
11.9 \\
17.3 \\
14.4 \\
9.7 \\
6.1 \\
4.6 \\
10.5 \\
10.5 \\
14.5\end{aligned}$ & $\begin{array}{l}52.3 \\
52.1 \\
54.6 \\
50.3 \\
36.3 \\
41.5 \\
41.9 \\
38.8 \\
39.0 \\
55.0\end{array}$ & $\begin{array}{l}210-260 / 140-148 \\
246-278 / 138-160 \\
238-246 / 130-136 \\
228-232 / 128-134 \\
122-246 / 70-140 \\
126-148 / 74-88 \\
124-134 / 76-80 \\
130-138 / 76-80 \\
126-140 / 70-76 \\
132-140 / 70-78\end{array}$ & $\begin{array}{l}92-104 \\
84-116 \\
80 \\
76 \\
50-80 \\
52-60 \\
50-52 \\
50-56 \\
50-56 \\
52-55\end{array}$ & $\begin{array}{l}2.95 \\
3.10 \\
4.02 \\
2.91 \\
0.96 \\
0.64 \\
0.50 \\
0.50 \\
0.50 \\
0.68\end{array}$ \\
\hline $\begin{array}{l}\text { A. O. } \\
\text { Age } 47 \\
\text { Sex F } \\
\text { Ess. Hyr } \\
\text { Post. Sy }\end{array}$ & 1.82 & 38.6 & $\begin{array}{l}0.13 \mathrm{mg} \cdot \\
0.02 \mathrm{mg} \cdot \times 16\end{array}$ & $\begin{array}{r}20 \\
20 \\
\longrightarrow \\
20 \\
40 \\
40 \\
40 \\
40 \\
40 \\
37 \\
30\end{array}$ & $\begin{array}{l}\mathbf{5 7 . 4} \\
63.4 \\
61.4 \\
50.3 \\
55.7 \\
53.1 \\
55.6 \\
55.7 \\
60.0 \\
54.7\end{array}$ & $\begin{array}{l}336 \\
377 \\
362 \\
326 \\
376 \\
350 \\
358 \\
357 \\
368 \\
363\end{array}$ & $\begin{array}{l}190-208 / 122-128 \\
194-208 / 120-128 \\
208-212 / 126-130 \\
152-210 / 92-126 \\
150-164 / 96-100 \\
160-174 / 98-108 \\
156-180 / 94-108 \\
158-170 / 98-102 \\
158-168 / 94-102 \\
162-168 / 100-104\end{array}$ & $\begin{array}{l}70-76 \\
72-74 \\
70-76 \\
56-72 \\
56-60 \\
56-60 \\
56-64 \\
56-60 \\
56 \\
56-60\end{array}$ & $\begin{array}{l}4.70 \\
4.40 \\
3.50 \\
1.20 \\
0.73 \\
0.88 \\
0.73 \\
1.00 \\
1.14 \\
1.13\end{array}$ \\
\hline $\begin{array}{l}\text { M. B. } \\
\text { Age } 42 \\
\text { Sex F } \\
\text { Ess. Hyr } \\
\text { Post. Sy }\end{array}$ & 1.63 & 38.2 & $\begin{array}{l}0.11 \mathrm{mg}:- \\
1 \mathrm{\mu g} . / \mathrm{min} .\end{array}$ & 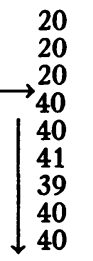 & $\begin{array}{l}78.4 \\
74.6 \\
76.7 \\
66.0 \\
70.8 \\
73.6 \\
70.9 \\
79.7 \\
73.3\end{array}$ & $\begin{array}{l}415 \\
385 \\
385 \\
359 \\
402 \\
388 \\
415 \\
388 \\
347\end{array}$ & $\begin{array}{l}198-204 / 112-128 \\
210-222 / 120-130 \\
204-222 / 122-124 \\
150-218 / 90-126 \\
150-166 / 90-96 \\
144-156 / 88-94 \\
146-150 / 80-92 \\
132-144 / 80-86 \\
134-140 / 80-86\end{array}$ & $\begin{array}{l}60-70 \\
60-66 \\
62-64 \\
52-62 \\
52-54 \\
48-54 \\
46-50 \\
45-48 \\
44-48\end{array}$ & $\begin{array}{l}3.90 \\
6.80 \\
6.35 \\
1.60 \\
0.60 \\
0.39 \\
0.56 \\
0.45 \\
0.35\end{array}$ \\
\hline
\end{tabular}


TABLE I-Continued

\begin{tabular}{|c|c|c|c|c|c|c|c|c|c|}
\hline Pt. & BSA & Hct. & $\begin{array}{l}\text { Admin. of } \\
\text { proto. }\end{array}$ & Period & GFR。 & $\mathrm{ERPF}_{\mathrm{c}}$ & B.P. range & H.R. & U.F. \\
\hline $\begin{array}{l}\text { D. Z. } \\
\text { Age } 26 \\
\text { Sex M } \\
\text { Normal }\end{array}$ & 1.80 & 40.1 & $\begin{array}{l}3.8 \mu \mathrm{g} . / \mathrm{min} . \\
1 \mu \mathrm{g} . / \mathrm{min} .\end{array}$ & $\begin{array}{r}\min . \\
20 \\
20 \\
22 \\
\downarrow 36 \\
40 \\
40 \\
40 \\
40 \\
40\end{array}$ & $\begin{array}{c}c c . / \min . \\
100 . \\
111 . \\
90.5 \\
73.3 \\
77.2 \\
79.7 \\
80.9 \\
66.0 \\
71.2\end{array}$ & $\begin{array}{l}c c . / \min . \\
616 \\
675 \\
601 \\
557 \\
568 \\
574 \\
543 \\
440 \\
491\end{array}$ & $\begin{array}{l}\quad \mathrm{mm} . \mathrm{Hg} \\
118-122 / 66-70 \\
118-122 / 66 \\
122 / 68 \\
124-126 / 66 \\
126 / 66-68 \\
102-108 / 54 \\
106-108 / 52-58 \\
106-108 / 50-60 \\
106-108 / 50-60\end{array}$ & $\begin{array}{l}\text { per min. } \\
64-72 \\
66-72 \\
70 \\
70 \\
64 \\
54 \\
52-54 \\
54-60 \\
50-54\end{array}$ & $\begin{array}{l}c c . / \min \\
0.80 \\
1.20 \\
2.41 \\
2.00 \\
0.80 \\
0.65 \\
0.55 \\
0.70 \\
0.40\end{array}$ \\
\hline $\begin{array}{l}\text { M. D. } \\
\text { Age } 39 \\
\text { Sex F } \\
\text { Normal }\end{array}$ & 1.72 & 44.7 & $\begin{array}{l}3.8 \mu \mathrm{g} . / \mathrm{min} . \\
1 \mu \mathrm{g} . / \mathrm{min} . \\
1 \mu \mathrm{g} . / \mathrm{min} .\end{array}$ & 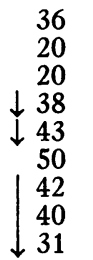 & $\begin{array}{l}85.2 \\
84.6 \\
74.7 \\
74.4 \\
66.5 \\
79.2 \\
69.5 \\
80.0 \\
71.1\end{array}$ & $\begin{array}{l}487 \\
575 \\
469 \\
422 \\
388 \\
472 \\
434 \\
518 \\
433\end{array}$ & $\begin{array}{l}102 / 70 \\
92-106 / 70-76 \\
98-106 / 70-74 \\
96-102 / 68-76 \\
84-104 / 46-66 \\
80-88 / 48-56 \\
90-98 / 56-64 \\
92-96 / 58-60 \\
90-94 / 56\end{array}$ & $\begin{array}{l}72-75 \\
74 \\
72 \\
69-72 \\
62-72 \\
60-68 \\
64-70 \\
70 \\
64\end{array}$ & $\begin{array}{l}1.03 \\
1.50 \\
3.60 \\
1.97 \\
0.61 \\
0.38 \\
0.60 \\
1.95 \\
3.87\end{array}$ \\
\hline
\end{tabular}

Key: $B S A$-body surface area. Hct.-Hematocrit. Admin. of proto.-intravenous administration of protoveratrine. Period min.-duration of period in minutes. $G F R_{c} c c . /$ min. and $E R P F_{c} c c . /$ min.- glomerular filtration rate and effective renal plasma flow corrected to a body surface area of 1.73 square meters. B.P. range $\mathrm{mm}$. $\mathrm{Hg}$ - the highest and lowest blood pressure values recorded during the period. H.R. per min.- highest and lowest heart rate during the period. U.F. cc./min. - urine flow.

the last 80 minutes of the infusion, for the 26 experiments in which the duration of the hypotension was at least three hours, was +9 per cent (range -17 per cent to +31 per cent).

Glomerular filtration rate fell promptly and strikingly (average -22 per cent, range -5 to -63 per cent for the 32 studies) when the blood pressure fell. Control values of GFR were regained in only one-quarter of the studies. In the remainder, control values were not reached up to three or more hours. The average GFR during the final 80 minutes of the infusion for the $26 \mathrm{ex}$ periments in which the hypotension was maintained at least three hours was -16 per cent (range -35 to +3 per cent).

The distribution of the percentage change in GFR and ERPF during the final 80 minutes of hypotension induced for at least two hours is indicated for the 32 studies in Figure 3. The data from the four normotensive individuals showed no significant variation from the hypertensive individuals. The data from four patients with chronic glomerulonephritis were not significantly different from those of hypertensive persons without obvious renal disease. The unshaded areas represent those with essential hypertension and four persons, not shown separately, with chronic glomerulonephritis and hypertension. The dimi- nution in GFR and the rise in ERPF is evident. The detailed data from 15 typical experiments are given in Table I. These include the eleven shown in Figures 1 and 2, two patients with bilateral thoraco-lumbar sympathectomy and two normotensive persons. Figure 4 depicts a typical experiment.

The two patients who had had previous thoracolumbar sympathectomy (A. O., one month postoperative; M. B., one and one-half years postoperative) showed hypotensive effects from protoveratrine similar to unoperated patients, yet neither showed the usual fall and subsequent rise in GFR and ERPF. This was particularly noticeable in patient $A$. O. who had also been studied before sympathectomy. Previous to operation there was a decrease in GFR and a marked increase in ERPF during the hypotensive period; after operation similar decrease in blood pressure caused essentially no change in ERPF and GFR.

Urine flow. In all instances the administration of protoveratrine caused a profound diminution in urine flow (Table I), frequently to less than 1.0 cc. per minute despite the constant intravenous infusion of 1.7 to $3.0 \mathrm{cc}$. of 0.9 per cent $\mathrm{NaCl}$ solution per minute, and, in some instances, 100 to $200 \mathrm{cc}$. of water orally every hour. The decrease in urine flow was the result of active re- 
sorption of glomerular filtrate water, as evidenced by a consistent, marked increase in the urinary concentration of inulin and PAH. Oliguria, as low as $0.5 \mathrm{cc}$. per minute was often present with normal or only moderately decreased clearances of inulin and PAH (see Table I). The mechanism of this oliguria and the excretion of sodium and potassium during it are described elsewhere (23).

\section{$V$ ariations in resistance of the afferent and efferent glomerular arterioles}

The hypotension induced by protoveratrine is accompanied by a marked fall in renal resistance units (RRU) (Figure 5). Figure 3 shows the distribution of the data from 24 experiments, including four normotensive individuals. In these patients calculations were based on the values obtained during the final 80 minutes of at least four hours of steadily maintained lowered blood pressure. The decrease in RRU was quite marked, the average fall being -27.5 per cent. Using the formulae derived by Lamport it appeared that the major part of this decreased resistance was due to a fall in afferent glomerular arteriolar resistance ( $\mathrm{Ra}$ ), the average change in $\mathrm{Ra}$ being - 53 per cent. Only a small portion of the total decrease was due to diminution in efferent glomerular arteriolar resistance $(\mathrm{Re})$, in which the average change was -14 per cent.

For 15 hypertensive patients there were sufficient data to allow calculation of $\mathrm{Ra}$ and $\mathrm{Re}$ according to the formulae suggested by Gómez (21). In every instance the direction and magnitude of the changes following prolonged hypotension were similar to those obtained by Lamport's formulae. The average changes of $\mathrm{Ra}$ and $\operatorname{Re}$ (Lamport) at the end of four hours of maintained hypotension were -46 per cent and -10 per cent, respectively; the Gómez formulae showed decreases of - 40 per cent $(\mathrm{Ra})$ and -15 per cent $(\mathrm{Re})$. However, protoveratrine-induced hypotension in four normotensive individuals gave average changes in $\mathrm{Ra}$ of -57 per cent and in $\mathrm{Re}$ of +13 per cent (Lamport), contrasted with $\mathrm{Ra}$ of -26 per cent and $R e$ of 0 per cent (Gómez). The Lamport formulae obviously do not apply to hypotension in normal individuals, because unusually low or even negative values for $\mathrm{Ra}$ may be obtained.

Calculation of $\mathrm{Ra}$ and $\mathrm{Re}$ (Gómez) for seven of the patients in Table I (C. Mc., O. M., R. L., A. O., I. R., M. R., H. F.) indicated that the decrease in $\mathrm{Ra}$ was abrupt and usually accompanied the blood pressure fall, reaching lowest values in about one hour (Figure 5). The decrease in $\mathrm{Re}$ was of smaller magnitude and in two of the seven patients insignificant. The decrease in $\mathrm{Ra}$ constituted the major portion of the diminution in renal resistance (Figure 5).

In the two patients who had had sympathectomy, decrease in $\mathrm{Ra}$ was similar to unoperated patients. $\operatorname{Re}$ remained unchanged.

\section{DISCUSSION}

A desirable hypotensive agent should cause a decrease in blood pressure without reducing blood flow or function in any vital part of the body. It is well known, for example, that in patients with coronary artery disease abrupt or prolonged falls in blood pressure may lead to coronary occlusion or myocardial infarction (24). However, the lowered blood pressure which results from the use of protoveratrine, at least within a certain dosage range, appears to be due primarily to a release of arteriolar vasoconstriction and diminution of total peripheral resistance. It therefore differs from the hypotension which occurs after a sudden decrease in effective circulating blood volume as in acute hemorrhage. Patients O. M. and R. L., in Table I, illustrate that marked hypotension can be maintained with protoveratrine without diminishing renal blood flow. Hoobler, Corley, and Kabza (3) have demonstrated that protoveratrine causes diminished resistance in the limb vessels in hypertensive patients. A similar decreased resistance in the cerebral vessels has been reported by Crumpton and his associates (25). Nonetheless, it still is possible that unusually prolonged and severe hypotensive action from protoveratrine might result in impaired circulation to vital areas such as heart or brain, particularly in the presence of atherosclerosis.

The degree of renal vasodilation which can be induced by protoveratrine hypotension may be a measure of the functional vasoconstriction present in the kidney. This vasodilation differs from that which occurs in hypertensive persons during fever, since the latter takes place during the period of increased cardiac output (26). Renal vasodilation after protoveratrine is not confined to es- 
sential hypertension, but occurs also in chronic glomerulonephritis. In patients with chronic renal disease, even with nitrogen retention ( $E . P$. and $\mathrm{A}$. $\mathrm{P}$. in Table $\mathrm{I}$ ), maintaining a steady lowered level of blood pressure is associated with restoration of ERPF to control (hypertensive) levels, and a fall in total renal resistance. In individuals with essential hypertension, ERPF may rise considerably above control levels as the blood pressure is maintained at a steady low level (A. A. and A. O. in Table I). Patients with benign essential hypertension and $\mathrm{PAH}$ clearance of 300 to $400 \mathrm{cc}$. have normal extraction ratios of $\mathrm{PAH}$ (27-29). In these, at least, any rise in ERPF means increased blood flow. In those patients with chronic renal insufficiency in whom extraction ratios are diminished $(27,29)$ either a decreased in renal vasoconstriction or, what is less likely, an improvement in extraction ratio has obviously occurred as a result of the lowered pressure.

Although ERPF always recovered to or above control values during hypotension prolonged for two to four hours, this was not true of glomerular filtration rate. In only one-fourth of the patients did GFR regain control levels, the average value being diminished by 16 per cent at the end of three to four hours. For individuals whose filtration rate is at least one-half normal, such falls are of little consequence. Patients on rigid sodium restriction have similar decreases in GFR (30) without any rise in non-protein nitrogen. However, in the presence of severe nitrogen retention and very low filtration rates, a small additional fall in GFR might be sufficient to cause further rise in NPN. Actually, when administering protoveratrine by various routes to patients with nitrogen retention for as long as seven weeks, we have noted slight rises in NPN, no change, and in some cases a significant fall (31).

Gómez has suggested that the predominant change in the renal circulation in hypertension is an increase in afferent glomerular arteriolar resistance (21), rather than efferent glomerular arteriolar resistance, as has been previously thought $(15,20)$. Analysis of the decrease in total renal resistance using Gómez' (or Lamport's) formulae indicates that it is primarily the afferent arteriole which dilates as the systemic pressure diminishes.
The data from the two sympathectomized patients, although scanty, suggest that the denervated kidneys in essential hypertension do not respond to vasodepressor influences with variations in filtration rate and blood flow as do the normally innervated ones. This is of interest in comparison with the data of Pfeiffer and Wolff (32) which indicated that the functional response of the kidney to pressor influences was altered similarly by sympathectomy.

\section{SUMMARY}

1. Renal clearances of inulin and $\mathrm{PAH}$ have been studied 43 times in 36 subjects, 32 with hypertension, before and after induction of hypotension with protoveratrine.

2. Effective renal plasma flow was usually diminished (average -8 per cent) with the acute onset of hypotension, but usually rose in one and one-half hours to control levels or higher, although the hypotension was maintained.

3. Glomerular filtration rate usually fell strikingly (average -22 per cent) with the onset of hypotension. After three hours of steadily maintained hypotension, GFR averaged 16 per cent below control levels. At the end of four hours GFR did regain control values in one-fourth of the patients.

4. Oliguria characteristically appeared when the blood pressure was lowered. Recovery to control values of GFR or ERPF often took place despite persistence of the oliguria, which usually lasted several hours.

5. Renal vasodilation occurred in patients with essential hypertension as well as those with chronic glomerulonephritis when the blood pressure was maintained at a lowered level with protoveratrine.

6. Calculation of changes in afferent and efferent resistance using Gómez' formulae indicated that the major decrease in renal resistance during the period of hypotension occurred at the afferent glomerular arteriole. The decreases in afferent and efferent arteriolar resistance were similar whether calculated by Gómez' or Lamport's formulae.

\section{REFERENCES}

1. Wilkins, R. W., Veratrum viride in hypertensive cardiovascular disease. Mod. Concepts Cardiovas. Dis., 1951, 20, 89. 
2. Meilman, E., and Krayer, O., Clinical studies on veratrum alkaloids. I. The action of protoveratrine and veratridine in hypertension. Circulation, 1950, 1, 204.

3. Hoobler, S. W., Corley, R. W., and Kabza, T. G., Effects of protoveratrine on the circulation in hypertension. J. Clin. Invest., 1951, 30, 651.

4. Salzberger, G., Utber die Alkaloide der weissen Nieswurz (Veratrum Album). Arch. d. Pharmazie, 1890, 228, 462.

5. Meilman, E., and Krayer, O., Clinical studies on veratrum alkaloids. II. The dose-response relations of protoveratrine in hypertension. Circulation, 1952, 6, 212.

6. Krayer, O., and Acheson, G. H., The pharmacology of the veratrum alkaloids. Physiol. Rev., 1946, 26, 383.

7. Dawes, G. S., Studies on veratrum alkaloids. VII. Receptor areas in the coronary arteries and elsewhere as revealed by the use of veratridine. $\mathrm{J}$. Pharm. \& Exper. Therap., 1947, 89, 325.

8. Bezold, A. von, and Hirt, L., Uber die physiologischen Wirkungen des essigsauren Veratrins. Unters. physiol. Lab. Würzberg, 1867, 1, 73.

9. Cramer, W., On the action of veratrum viride. With some remarks on the interrelationship of the medullary centres. J. Pharm. \& Exper. Therap., 1915, 7, 63.

10. Jarisch, A. H., and Richter, H., Die afferenten Bahnen des Veratrineffektes in den Herznerven. Arch. $f$. exper. Path. u. Pharmakol., 1939, 193, 355.

11. Freis, E. D., Stanton, J. R., Culbertson, J. W., Litter, J., Halperin, M. H., Burnett, C. H., and Wilkins, R. W., The hemodynamic effects of hypotensive drugs in man. I. Veratrum viride. J. Clin. Invest., 1949, 28, 353.

12. Mendez, R., and Montes, G., Studies on veratrum alkaloids. III. Qualitative and quantitative differences in the action of cevine and veratridine. $\mathrm{J}$. Pharm. \& Exper. Therap., 1943, 78, 238.

13. Maison, G. L., Gotz, E., and Stutzman, J. W., Relative hypotensive activity of certain veratrum alkaloids. J. Pharm. \& Exper. Therap., 1951, 103, 74.

14. Krayer, O., Studies on veratrum alkaloids. VIII. Veratramine, an antagonist to the cardioaccelerator action of epinephrine. J. Pharm. \& Exper. Therap., 1949, 96, 422.

15. Goldring, W., and Chasis, H., Hypertension and $\mathrm{Hy}-$ pertensive Disease. New York, The Commonwealth Fund, 1944.

16. Roe, J. H., Epstein, J. H., and Goldstein, N. P., A photometric method for the determination of inulin in plasma and urine. J. Biol. Chem., 1949, 178, 839.

17. Smith, W. W., Finkelstein, N., and Smith, H. W., Renal excretion of hexitols (sorbitol, mannitol, and dulcitol) and their derivatives (sorbitan, isomannide, and sorbide) and of endogenous creatine-like chromogen in dog and man. J. Biol. Chem., 1940, 135, 231.

18. Gilman, A., Philips, F. S., and Koelle, E. S., The renal clearance of thiosulfate with observations on its volume distribution. Am. J. Physiol., 1946, 146, 348.

19. Bratton, A. C., and Marshall, E. K., Jr., A new coupling component for sulfanilamide determination. J. Biol. Chem., 1939, 128, 537.

20. Lamport, H., Formulae for afferent and efferent arteriolar resistance in the human kidney: An application to the effects of spinal anesthesia. J. Clin. Invest., 1941, 20, 535.

21. Gómez, D. M., Evaluation of renal resistances, with special reference to changes in essential hypertension. J. Clin. Invest., 1951, 30, 1143.

22. Smith, H. W., Lectures on the Kidney. University of Kansas, 1943, p. 57.

23. Meilman, E., The mechanism of protoveratrine-induced oliguria. J. Clin. Invest., 1952, 31, 649.

24. Blumgart, H. L., Schlesinger, M. J., and Zoll, P. M., Multiple fresh coronary occlusions in patients with antecedent shock. Arch. Int. Med., 1941, 68, 181.

25. Crumpton, C. W., Friedland, C. K., Kuo, P. T., Schnabel, T. G., Jr., Foltz, E. L., Page, R. G., Alanis, J., and Hafkenschiel, J. H., The hemodynamic actions of protoveratrine in essential hypertension. J. Clin. Invest., 1951, 30, 634.

26. Grollman, A., Variations in the cardiac output of man. V. The cardiac output of man during the malaise and pyrexia following the injection of typhoid vaccine. J. Clin. Invest., 1929, 8, 25.

27. Bradley, S. E., Curry, J. J., and Bradley, G. P., Renal extraction of $p$-aminohippurate in normal subjects and in essential hypertension and chronic diffuse glomerulonephritis. Federation Proc., 1947, 6, 79.

28. Reubi, F. C., and Schroeder, H. A., Can vascular shunting be induced in the kidney by vasoactive drugs? J. Clin. Invest., 1949, 28, 114.

29. Cargill, W. H., The measurement of glomerular and tubular plasma flow in the normal and diseased human kidney. J. Clin. Invest., 1949, 28, 533.

30. Chasis, H., Goldring, W., Breed, E. S., Schreiner, G. E., and Bolomey, A. A., Salt and protein restriction. J. A. M. A., 1950, 142, 711.

31. Meilman, E., Unpublished observations.

32. Pfeiffer, J. B., Jr., and Wolff, H. G., Studies in renal circulation during periods of life stress and accompanying emotional reactions in subjects with and without essential hypertension: Observations on the role of neural activity in regulation of renal blood flow. J. Clin. Invest., 1950, 29, 1227. 